\title{
Moderating Effect of Implementation Risk-Based Auditing on Audit Quality
}

\author{
Entar Sutisman $^{1 *}$, Yana Ermawati ${ }^{2}$, Siti Mariani $^{3}$, Kartim $^{4}$, Aditya Halim Perdana \\ Kusuma Putra ${ }^{5}$ \\ 1,2,3,4 Department of Accounting, Faculty of Economic and Business, University Yapis Papua, \\ Papua, Indonesia5 \\ ${ }^{5}$ Department of Management, Faculty of Economic and Business, Universitas Muslim Indonesia, \\ Makassar, Indonesia \\ Email address: \\ entar.uniyap@gmail.com ${ }^{1}$,ermawati.yana@gmail.com², sitimariani78@gmail.com3, \\ kartim321@gmail.com ${ }^{4}$ adityatrojhan@gmail.com ${ }^{5}$ \\ ${ }^{*}$ Corresponding author
}

\begin{abstract}
This study aims to examine the effect of the ability and independence of auditors on audit quality by using risk-based auditing as a moderating variable at the Inspectorate of South Sulawesi Province. The population in this study were all auditors at the Inspectorate of South Sulawesi Province, using the purposive sampling method for sample selection so that 35 respondents were selected as samples. This research uses field research methods. This study used a survey method for field data collection, namely by distributing questionnaires to the research object. The statistical method used to test the hypothesis is to use multiple linear regression with the help of Smart PLS 3.0 software. The analysis results show that the ability and independence of the auditors have a positive and significant effect on audit quality. The application of risk-based auditing as a moderator of capability and freedom also positively impacts audit quality.
\end{abstract}

Keywords: Competence, Independence, Risk Based Audit, Audit Quality.

\begin{abstract}
Abstrak: Penelitian ini bertujuan untuk menguji pengaruh kemampuan dan independensi auditor terhadap kualitas audit dengan menggunakan audit berbasis risiko sebagai variabel pemoderasi pada Inspektorat Provinsi Sulawesi Selatan. Populasi dalam penelitian ini adalah seluruh auditor pada Inspektorat Provinsi Sulawesi Selatan, dengan menggunakan metode purposive sampling untuk pemilihan sampel sehingga terpilih 35 responden sebagai sampel. Penelitian ini menggunakan metode penelitian lapangan. Penelitian ini menggunakan metode survei untuk pengumpulan data lapangan, yaitu dengan menyebarkan kuesioner kepada objek penelitian. Metode statistik yang digunakan untuk menguji hipotesis adalah dengan menggunakan regresi linier berganda dengan bantuan software Smart PLS 3.0. Hasil analisis menunjukkan bahwa kemampuan dan independensi auditor berpengaruh positif dan signifikan terhadap kualitas audit. Penerapan audit berbasis risiko sebagai moderator kapabilitas dan kebebasan juga berdampak positif terhadap kualitas audit.
\end{abstract}

Kata kunci: Kompetensi, Independensi, Audit Berbasis Risiko, Kualitas Audit. 


\section{INTRODUCTION}

The inspectorate is an institution assigned to carry out a supervision to realize a government administration following the law, as described in Article 1 paragraph 2 of Government Regulation Number 12 of 2017 concerning Guidance and Supervision of Regional Government Administration, which states that "government administration activities are devoted to ensuring good local governance following applicable regulations. Every government agency must carry out the attitude of transparency and responsibility because this is intended so that the public does not misunderstand when interpreting reports of what has been done by the government. Errors in analyzing financial information will be able to influence making a decision. Therefore, the disclosure of financial statements provided by the government must meet the demands of applicable regulations and encourage public understanding of government management through the information presented (Ihsanti, 2014). The supervisory function must always pay attention to implementing management functions, such as planning, organizing, and monitoring all operational activities within the organization. The supervisory position is one of the practical supervisory functions because abnormalities will be easier and faster to find.

The needs of the people who want clean, dignified, and law-abiding state institutions. The inspectorate is one of the parties overseeing the financial reporting process. Following its function as Government Internal Supervisory Apparatus (APIP), supervisors must make the public have confidence in the effectiveness and efficiency of work to achieve the objectives of managing government administration. Therefore, supervisors are required to increase public confidence in the function of the government's internal supervisory agency.

The auditor must be competent and independent to produce a good audit quality. Auditor competence is required to conduct an audit. Auditor competencies will be tested based on their knowledge and experience (Ningtyas et al., 2016). The auditor must have knowledge that is measured by his level of education. In this way, the auditor will have more knowledge (views) about the field he is involved in to find more information about various issues. Auditors must also have experience in conducting audits. The longer the auditor performs the audit, the more experience they have as auditors. As an auditor, work experience must have excellence in finding faults, in-depth understanding of errors, and finding root causes of problems. In addition to knowledge and experience, the auditor must also have an independent attitude and high quality. Independent attitude. (Luh et al., 2015) Luh argues that independence is a good or spiritual attitude of the auditor in the audit process. In this case, the auditor must have an impartial bias against other parties.

The main task of the inspectorate is to carry out a supervisory function to ensure quality or provide guarantees so that government administration has run as it should. Limited resources such as the number of auditors/supervisors, the budget, and the limited facilities/infrastructure available will be obstacles in achieving the audit objectives. Therefore, an audit method must direct these limited resources to the center of risk, which becomes an obstacle to achieving regional development goals. If the supervisory function does not run typically, it won't be easy to achieve its objectives. Therefore, instructions will be used to support the effectiveness of the monitoring plan.

(Elizabeth and Laksito, 2017) define audit quality as the probability that the auditor will find and report violations in the client's accounting system. The results of the violation investigation measure the quality of the auditor's knowledge and expertise. At the same time, 
reporting of violations depends on whether the auditor encourages disclosure of breaches. This incentive will depend on the independence of the auditor. Many factors affect the ability of auditors, including knowledge and experience. To carry out audit duties, auditors need audit knowledge (general and specific) and knowledge of the auditing, accounting, and client industries.

(Setyowati, 2019) found that the wealth of an area will always have a positive relationship with the disclosure of accountability reports provided by local/city governments. In addition, this study also found that the richer the potential of an area, the higher the level of openness by the local government. Therefore, to achieve the previously planned objectives, an audit method is needed to reduce or prevent these risks. This method is called a risk-based audit. A risk-based audit is an audit based on the results of a risk assessment, which can hinder the achievement of objectives so that a more targeted plan and more targeted implementation are obtained, resulting in a quality report (Trianto, 2017).

This study takes reference from research that has been conducted by (Purnamasari and Merkusiwati, 2017) which examines the effect of task complexity, independence, and competence on audit quality with auditor integrity as a moderating variable. The thing that is different from this research and research (Purnamasari and Merkusiwati, 2017) is the additional research locations. (Purnamasari and Merkusiwati, 2017) Has also researched complexity and integrity. In this study, task complexity and integrity assessment have been removed and replaced with a competency assessment and the implementation of risk-based auditing.

This study used two theories, namely attribution theory and agency theory. The attribution theory proposed by (Raharjo, 2005) explains that the reasons for a person's behavior are determined internally (such as traits, personality, etc.) or externally (such as a stressful environment that can affect everyone's behavior). (Adianita et al., 2017) explained, attribution theory is a theory that describes how people determine the causes and motivations of their actions. According to (Yovita and Rahmawaty, 2016), this theory can be divided into two types, namely internal attribution and external attribution. While agency theory, according to (Lesmana and Machdar, 2015), is a contract in which one or more people (persons) employ other people (agents) to provide various services and delegate decision-making authority to agents. According to (Eisenhardt, 1989) agency theory can be divided into several hypotheses used as the basis, namely the assumption about human nature, the idea about the organization, and information. Agency theory can be formed in the contract model between two or more people (the parties) in the contract model between the government (agent) and the community (principal). The agent has authorization from the principal and can carry out all activities on behalf of the principal referred to in determining a decision (Lesmana and Machdar, 2015).

(Anis, 2014) explains that auditing is a process of strictly and systematically examining financial statements by an independent party to provide an opinion. (Duréndez Gómez-Guillamón and Maté Sanchez-Val, 2012) defines auditing as a systematic process of evaluating evidence objectively based on established standards. (Hai et al., 2019) argue that audit quality is a professional standard in conducting audits. These standards will be a benchmark for the quality of auditor performance (Ilham et al., 2019). (Simanjuntak, 2008) believes that audit quality is a systematic examination that can determine the quality of plans according to the rules set to achieve goals. (Arianti et al., 2014) define audit quality so that auditors can find and report reports on the client's accounting system. If a competent and 
independent auditor carries out the audit, it can be said that the audit quality is high. Qualified auditors refer to those who have technical capabilities and skills and understand and apply the correct audit procedures and techniques to detect a deviation. (Mansouri et al., 2009) stated that a person is said to be competent when someone has the knowledge and skills in carrying out and applying their duties and functions at work. (Meidawati and Assidiqi, 2019) view that a competent auditor is an auditor who has the knowledge and ethical behavior at work so that competence can show an achievement. On the other hand, according to (Muslim et al., 2020), competence is the attitude of specific skills that must be possessed; these skills are obtained through education and experience for review. Capability is an essential factor affecting audit quality. To support when determining the decision to be taken, an auditor must have sufficient ability and experience in understanding a criterion for deciding evidence.

(Ardhani et al., 2019) Independence is an audit standard needed to maintain trust in financial statements that represent company management. If the auditor is not independent of the client's leadership, his opinion will not be influential. Independence is an attitude that is free, uncontrolled, and dependent on other parties (Prasanti et al., 2019). When considering facts and expressing opinions, independence equates to transparency and fairness. Independence is defined as using a neutral point of view in the implementation process, evaluating audit test results, and reporting audit results (Ahmad, 2015). External auditors need an independent attitude in providing audit services to users of financial statements. In addition, the independence of external auditors is also an essential factor in evaluating the quality of the audit services provided. auditing

Risk-based is one of the methods used by internal auditors in carrying out audit tasks to ensure that management can appropriately manage existing risks and has a risk limit that does not affect the company's objectives. In general, the risk is defined as an event or situation related to obstacles or problems in achieving a goal. Understanding risk is related to the existence of a plan. If there is no goal, there is no risk (Zhang et al., 2011). According to (Asseldonk and Velthuis, 2014), audit risk refers to the auditor's inaccurate opinion on the financial statements about material misstatements. To reduce the level of risk accepted by the auditor, a risk-based audit needs to be carried out to achieve the audit objectives. According to (Sulaiman et al., 2019), the difference between risk-related audit methods and conventional audit methods lies in the method used. The auditor reduces his focus on testing individual transactions and focuses more on how test management addresses realization. The target of system and process barriers and an effort to assist management in overcoming (diverting) obstacles caused by risk factors in decision making. Based on the description above, the conceptual framework of our research is: 


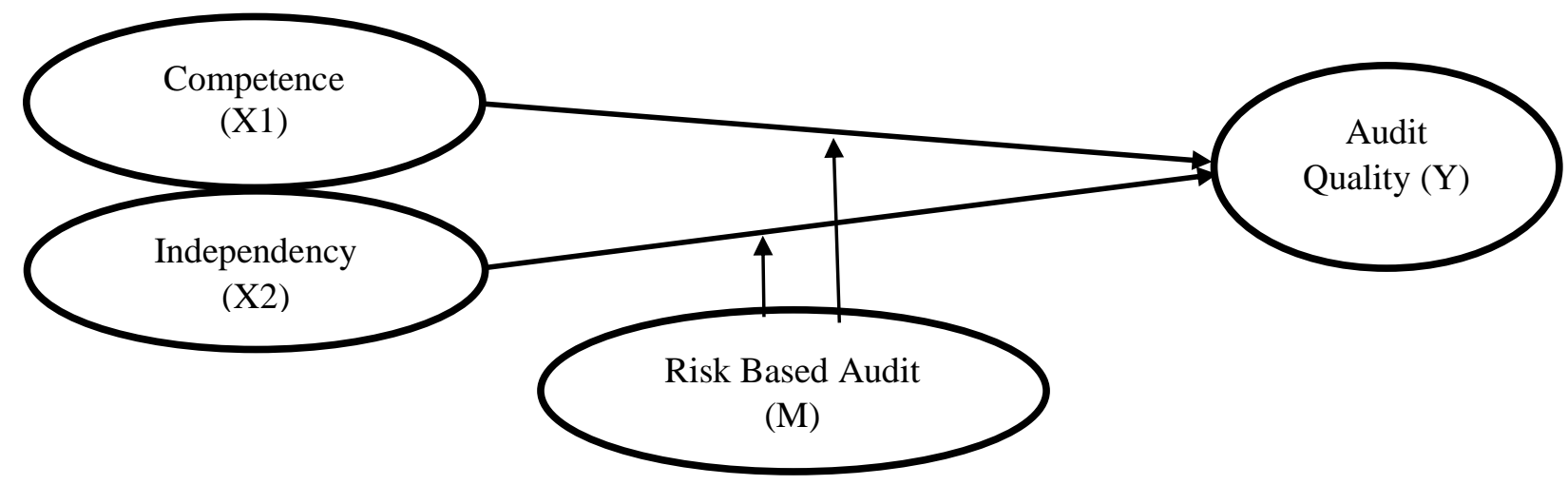

Figure 1. Research Model

Based on the description and conceptual framework that has been described previously, the hypotheses in our research are:

H1: competence has a positive effect on audit quality

H2: Independence has a positive impact on Audit Quality

H3: Competence affects audit quality if moderated by risk-based audit

H4: Independence affects audit quality if moderated by risk-based audit.

\section{METHODS}

Our research uses quantitative methods. This research was conducted at the South Sulawesi Inspectorate Office, Makassar City, South Sulawesi Province. The time required in this study is two months, from January 2021 to March 2021. In this study, the population we use are all auditors at the Inspectorate of South Sulawesi Province. The data provided by the Inspectorate is 35 auditors, consisting of 16 auditors, middle experts, 18 junior expert auditors, and 1 Pratama expert auditor. In this study, a census sampling technique was used because all members of the population were used as research samples. After all, the sample size was small (35 people), so this technique was used. This research uses field research methods. This study used a survey method for field data collection, namely by distributing survey forms to research subjects. The type of data we use in this study is quantitative data, namely data in answers to questions or questionnaire scores. At the same time, the source of data that we employ in this study is primary data. Primary data is data obtained from field research, namely direct observation of the object to be studied through data collection techniques in questionnaires. The statistical method used to test the hypothesis is to use multiple linear regression with the help of Smart software PLS 3.0. 


\section{RESULTS}

Table 1. Data on Gender of Respondents

\begin{tabular}{cccc}
\hline No & Gender & n & \% \\
\hline 1 & Men & 23 & $65,71 \%$ \\
2 & Women & 12 & $34,29 \%$ \\
\hline & Total & 35 & $100 \%$ \\
\hline
\end{tabular}

Source: Processed primary data, 2021

Based on Table 1, 35 respondents from the Supervisory Service of South Sulawesi are auditors, consisting of 23 males $(65.71 \%)$ and 12 females $(34.29 \%)$. It can be seen from the figure that there are more male respondents than female respondents.

Table 2. Respondents Work Period Data

\begin{tabular}{cccc}
\hline No & Length of work (years) & n & \% \\
\hline 1 & $<3$ & 1 & $2,86 \%$ \\
2 & $>3$ & 34 & $97,14 \%$ \\
\hline & Total & 35 & $100 \%$ \\
\hline
\end{tabular}

Source: Processed primary data, 2021

Table 2 shows that most auditors worked less than three years, i.e., one auditor, accounting for $2.86 \%$ of the total number of respondents. Meanwhile, 34 auditors have worked for more than three years or reached $97.14 \%$.

Table 3. Data on the Position of Respondents

\begin{tabular}{clcc}
\hline No & Position Level & n & \% \\
\hline 1 & Auditor Pertama & 1 & $2,86 \%$ \\
2 & Auditor Muda & 18 & $51,43 \%$ \\
3 & Auditor Madya & 16 & $45,71 \%$ \\
\hline & Total & 35 & $100 \%$ \\
\hline
\end{tabular}

Source: Processed primary data, 2021

Table 3 shows that of the 35 auditors working in the Supervisory Service of South Sulawesi Province, 1 or $2.86 \%$ is the first batch of auditors. At the same time, 18 or $51.43 \%$ of auditors are junior auditors, and 16 or $45.71 \%$ are middle auditors.

Research Instrument Test Results. Based on the number of variables and referring to the research questions, the data description is divided into four parts, namely ability (X1), independence (X2), risk-based auditing (M), and audit quality (Y). The complete descriptive statistical calculation results for each variable can be seen in the appendix. The following briefly shows the results of illustrative statistical calculations.

Competence (X1). Competence is a human attitude, meaning that humans must be reviewed through education and experience (Pinto et al., 2020). It can be seen from the results of the 
study that Table 4 shows the frequency distribution of respondents' responses to competence.

Table 4. Respondents' Responses Regarding Competence

\begin{tabular}{|c|c|c|c|c|c|c|c|c|c|}
\hline & \multirow{2}{*}{ Item } & \multicolumn{6}{|c|}{ Frequency Score and Percentage } & \multirow{2}{*}{ Total Score } & \multirow{2}{*}{ Mean } \\
\hline & & $\mathbf{1}$ & 2 & 3 & 4 & 5 & $\mathbf{N}$ & & \\
\hline \multirow{2}{*}{1} & $\mathrm{~F}$ & 0 & 0 & 2 & 16 & 17 & \multirow{2}{*}{35} & \multirow{2}{*}{155} & \multirow{2}{*}{4.4286} \\
\hline & $\%$ & 0 & 0 & 5,7 & 45,7 & 48,6 & & & \\
\hline \multirow{2}{*}{2} & $\mathrm{~F}$ & 0 & 0 & 1 & 17 & 17 & \multirow[b]{2}{*}{35} & \multirow{2}{*}{156} & \multirow{2}{*}{4.4571} \\
\hline & $\%$ & 0 & 0 & 2,9 & 48,6 & 48,6 & & & \\
\hline \multirow{2}{*}{3} & $\mathrm{~F}$ & 0 & 0 & 3 & 17 & 15 & \multirow{2}{*}{35} & \multirow{2}{*}{152} & \multirow{2}{*}{4.3429} \\
\hline & $\%$ & 0 & 0 & 8,6 & 48,6 & 42,9 & & & \\
\hline \multirow{3}{*}{4} & $\mathrm{~F}$ & 0 & 0 & 4 & 17 & 14 & \multirow{2}{*}{35} & \multirow{3}{*}{150} & \multirow{2}{*}{4.2857} \\
\hline & $\%$ & 0 & 0 & 11,4 & 48,6 & 40 & & & \\
\hline & \multicolumn{7}{|c|}{ Competence variable mean } & & 4.3786 \\
\hline
\end{tabular}

Source: Processed primary data, 2021

It can be seen from Table 4 that according to the statement used, most of the respondents assessed agreeing, while at least the respondents considered disagreeing. The total average of these four statements is 4.3786 , a scale of values indicating that the answer choices are very consistent.

Independence. Independence, an audit standard required to represent the credibility of management's financial statements (Sarwoko \& Agoes, 2014). It can be seen from the research results on the frequency distribution of respondents' responses to independence, as shown in Table 5.

Table 5. Respondents' Responses Regarding Independence

\begin{tabular}{|c|c|c|c|c|c|c|c|c|c|}
\hline \multirow{2}{*}{\multicolumn{2}{|c|}{ Item }} & \multicolumn{6}{|c|}{ Frequency Score and Percentage } & \multirow{4}{*}{$\begin{array}{c}\text { Total Score } \\
161\end{array}$} & \multirow{4}{*}{$\begin{array}{r}\text { Mean } \\
4.6\end{array}$} \\
\hline & & \multirow{3}{*}{$\begin{array}{l}\mathbf{1} \\
0 \\
0\end{array}$} & \multirow{2}{*}{$\begin{array}{l}\mathbf{2} \\
0 \\
\end{array}$} & \multirow{2}{*}{\begin{tabular}{|l|}
$\mathbf{3}$ \\
2 \\
\end{tabular}} & \multirow{2}{*}{$\begin{array}{c}\mathbf{4} \\
10 \\
\end{array}$} & \multirow{3}{*}{\begin{tabular}{|c|}
$\mathbf{5}$ \\
23 \\
65,7
\end{tabular}} & \multirow{3}{*}{$\begin{array}{l}\mathbf{N} \\
35\end{array}$} & & \\
\hline 1 & $\mathrm{~F}$ & & & & & & & & \\
\hline 1 & $\%$ & & 0 & 5,7 & 28,6 & & & & \\
\hline \multirow{2}{*}{2} & $\mathrm{~F}$ & 0 & 0 & 2 & 9 & 24 & \multirow{2}{*}{35} & \multirow{2}{*}{162} & \multirow{2}{*}{4.6286} \\
\hline & $\%$ & 0 & 0 & 5,7 & 25,7 & 68,6 & & & \\
\hline \multirow{2}{*}{3} & $\mathrm{~F}$ & 0 & 0 & 1 & 15 & 19 & \multirow{2}{*}{35} & \multirow{2}{*}{158} & \multirow{2}{*}{4.5143} \\
\hline & $\%$ & 0 & 0 & 2,9 & 42,9 & 54,3 & & & \\
\hline \multicolumn{9}{|c|}{ Independent variable mean } & 4.5810 \\
\hline
\end{tabular}

Source: Processed primary data, 2021

Table 5 shows that most respondents assessed strongly agreeing according to the statement items used, while a small proportion of respondents set disagreeing. The total mean of the three statements (i.e., 4.5810) is within the range of values, which indicates that the answer choices are the same.

Risk Based Audit (M). Risk-based auditing is defined as events or conditions related to obstacles to achieving goals. (van Asseldonk \& Velthuis, 2014). As can be seen from the 
research results, Table 6 shows the frequency distribution of respondents' responses to riskbased audits.

Table 6. Respondents' Responses Based on Risk-Based Audits

\begin{tabular}{|c|c|c|c|c|c|c|c|c|c|}
\hline & \multirow{2}{*}{ Item } & \multicolumn{6}{|c|}{ Frequency Score and Percentage } & \multirow{2}{*}{ Total Score } & \multirow{2}{*}{ Mean } \\
\hline & & 1 & 2 & 3 & 4 & 5 & $\mathbf{N}$ & & \\
\hline \multirow{2}{*}{1} & $\mathrm{~F}$ & 0 & 0 & 1 & 22 & 12 & \multirow{2}{*}{35} & \multirow{2}{*}{151} & \multirow{2}{*}{4.3143} \\
\hline & $\%$ & 0 & 0 & 2,9 & 62,9 & 34,3 & & & \\
\hline \multirow{2}{*}{2} & $\mathrm{~F}$ & 0 & 0 & 1 & 20 & 14 & \multirow{2}{*}{35} & \multirow{2}{*}{153} & \multirow{2}{*}{4.3714} \\
\hline & $\%$ & 0 & 0 & 2,9 & 57,1 & 40 & & & \\
\hline \multirow{2}{*}{3} & $\mathrm{~F}$ & 0 & 0 & 0 & 22 & 13 & \multirow{2}{*}{35} & \multirow{2}{*}{153} & \multirow{2}{*}{4.3714} \\
\hline & $\%$ & 0 & 0 & 0 & 62,9 & 37,1 & & & \\
\hline \multirow{2}{*}{4} & $\mathrm{~F}$ & 0 & 0 & 2 & 19 & 14 & \multirow{2}{*}{35} & \multirow{2}{*}{152} & \multirow{2}{*}{4.3429} \\
\hline & $\%$ & 0 & 0 & 5,7 & 54,3 & 40 & & & \\
\hline \multirow{3}{*}{5} & $\mathrm{~F}$ & 0 & 0 & 2 & 19 & 14 & \multirow{2}{*}{35} & \multirow{2}{*}{152} & \multirow{2}{*}{4.3429} \\
\hline & $\%$ & 0 & 0 & 5,7 & 54,3 & 40 & & & \\
\hline & \multicolumn{8}{|c|}{ Risk-Based Audit variable mean } & 4.3486 \\
\hline
\end{tabular}

Source: Processed primary data, 2021

It can be seen from Table 6, which shows that according to the statement used, the respondents who used the most gave a consistent assessment, while the respondents who used the least gave the opinion that they disagreed. The total average of the three statements is 4.3486, which indicates that the answer choices are very consistent on the numerical scale.

Audit Quality (Y). Audit quality is a systematic and independent examination that aims to determine the planned quality to comply with the rules set to achieve goals (Santosa et al., 2020). It can be seen from the research results on the frequency distribution of respondents' responses to audit quality, which is presented in Table 7.

Table 7. Respondents' Responses Based on Audit Quality

\begin{tabular}{|c|c|c|c|c|c|c|c|c|c|}
\hline & \multirow{2}{*}{ Item } & \multicolumn{6}{|c|}{ Frequency Score and Percentage } & \multirow{2}{*}{ Total Score } & \multirow{2}{*}{ Mean } \\
\hline & & $\mathbf{1}$ & 2 & 3 & 4 & 5 & $\mathbf{N}$ & & \\
\hline \multirow{2}{*}{1} & $\mathrm{~F}$ & 0 & 0 & 0 & 24 & 11 & \multirow{2}{*}{35} & \multirow{2}{*}{151} & \multirow{2}{*}{4.3143} \\
\hline & $\%$ & 0 & 0 & 0 & 68,6 & 31,4 & & & \\
\hline \multirow{2}{*}{2} & $\mathrm{~F}$ & 0 & 0 & 2 & 22 & 11 & \multirow{2}{*}{35} & \multirow{2}{*}{149} & \multirow{2}{*}{4.2571} \\
\hline & $\%$ & 0 & 0 & 5,7 & 62,9 & 31,4 & & & \\
\hline \multirow{2}{*}{3} & $\mathrm{~F}$ & 0 & 0 & 1 & 24 & 10 & \multirow{2}{*}{35} & \multirow{2}{*}{149} & \multirow{2}{*}{4.2571} \\
\hline & $\%$ & 0 & 0 & 2,9 & 68,6 & 28,6 & & & \\
\hline \multirow{2}{*}{4} & $\mathrm{~F}$ & 0 & 0 & 1 & 23 & 11 & \multirow{2}{*}{35} & \multirow{2}{*}{150} & \multirow{2}{*}{4.2857} \\
\hline & $\%$ & 0 & 0 & 2,9 & 65,7 & 31,4 & & & \\
\hline \multicolumn{9}{|c|}{ Mean of Audit Quality variable } & 4.2786 \\
\hline
\end{tabular}

Source: Processed primary data, 2021

Table 7 shows that based on the statements used, the respondents who used the most gave a consistent rating, while those who used the least gave the opinion that they disagreed. 
The total average of the four statements is 4.2786 , which indicates that the answer choices are very consistent.

Test First Order Confirmatory Factor Analysis. The first order construct test is carried out where the test will go through 1 level, the analysis is carried out from the latent construct to the indicators.

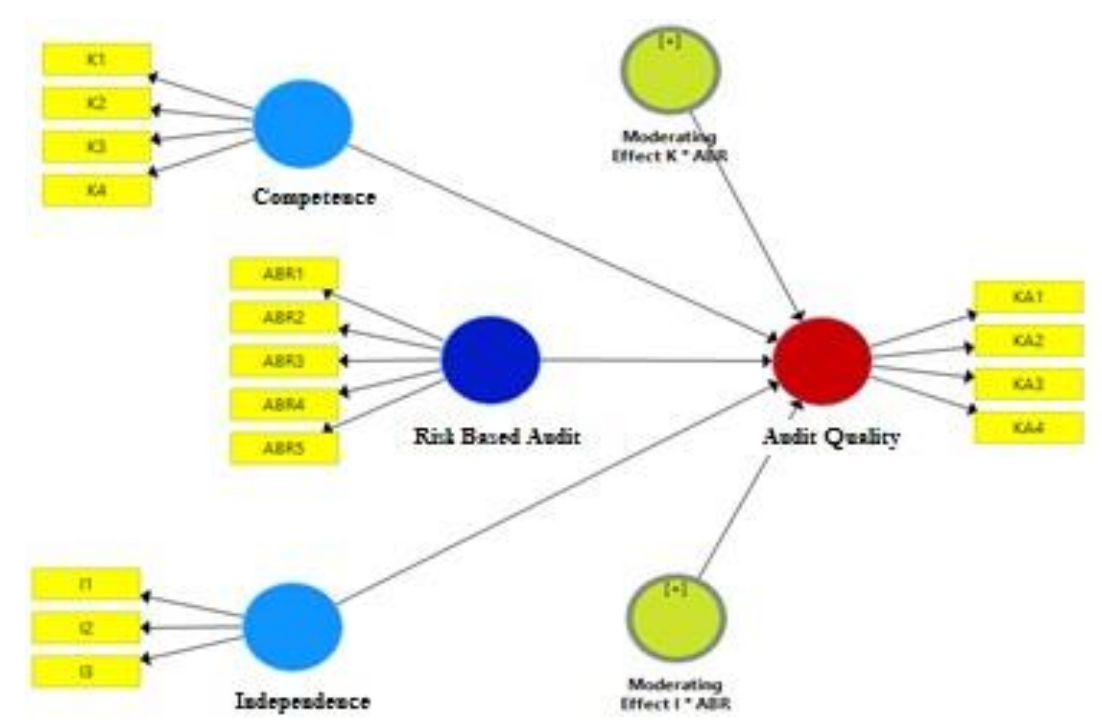

Figure 2. First Order Confirmatory Factor Analysis

It can be seen in Figure 2 that the competency structure of the first-order auditor is measured by indicators $\mathrm{K} 1-\mathrm{K} 4$. The first-order system of auditor independence is measured by indicators I1-I3. The first order is a risk-based audit structure with ABR1-ABR5 hands. The first-order structure of audit quality is measured by indicators KA1-KA4.

Structural Equation Model (SEM) Testing. The primary analytical method of our research is through the Structural Equation Model (SEM). The tests were carried out with the help of the Smart PLS 3.0 program. The following is the result of using Intelligent PLS to test the complete SEM model, as shown in Figure 3. 


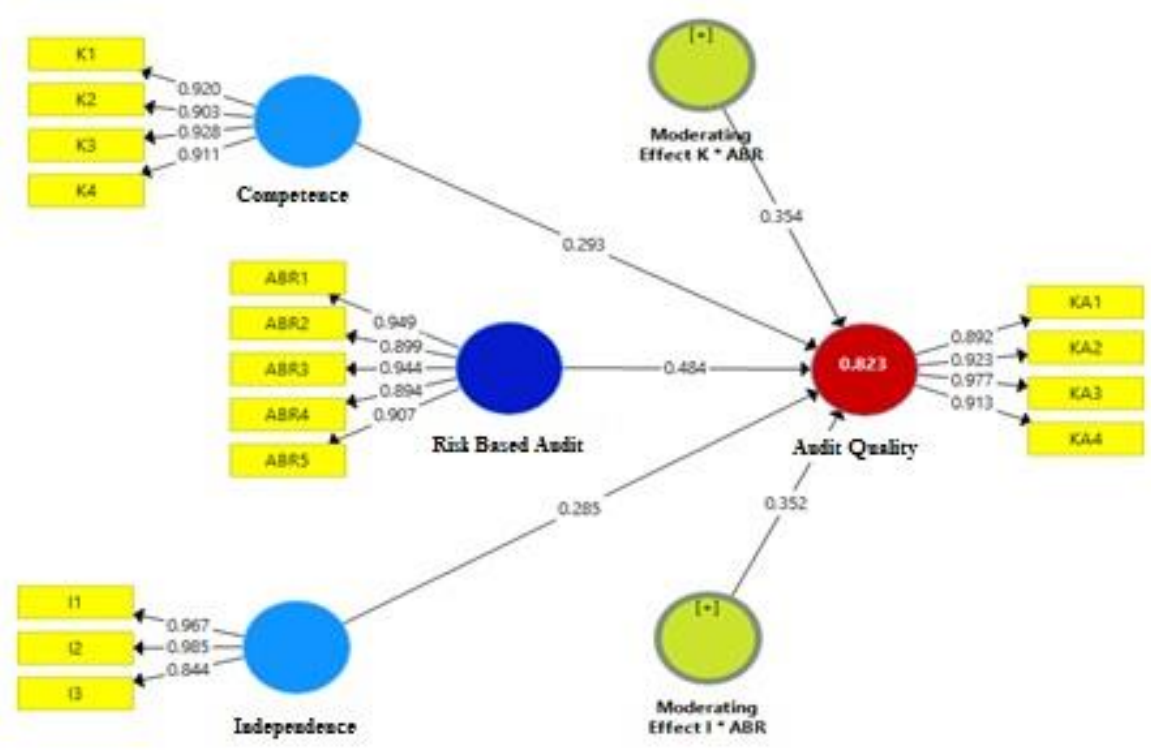

Figure 3. Full SEM Model Test Using Smart PLS

Based on the test results using smart PLS shown in Figure 3, it can be seen that there is no load factor value lower than 0.50 , so there is no need to delete data to delete indicators with load values lower than 0.50 to get a good example.

Test Outer Model. In this test, three measurement methods are used in data analysis techniques using the Smart PLS evaluation model. The three measurements are convergent validity, composite reliability and discriminant validity.

Table 8. Test of Outer Loading Validity of Auditor Competency Variables

\begin{tabular}{lcc}
\hline & Competence & Info \\
\hline K1 & 0.920 & Valid \\
K2 & 0.903 & Valid \\
K3 & 0.928 & Valid \\
K4 & 0.911 & Valid \\
\hline
\end{tabular}

Source: Processed primary data, 2021

It can be seen from Table 8 that the estimated results of the outer loading test calculation using PLS as an indicator of the auditor's ability variable. The table shows that the loading coefficients $\mathrm{K} 1$ to $\mathrm{K} 4$ as a reflection index are $>0.70$, which means that all construction indices are valid. The conclusion is that all indicators effectively measure the structure of the auditor's competence variable. 
Table 9. Outer Loading Validity Test of Auditor's Independent Variables

\begin{tabular}{ccc}
\hline & Independence & Info \\
\hline I1 & 0.967 & Valid \\
I2 & 0.985 & Valid \\
I3 & 0.844 & Valid \\
\hline
\end{tabular}

Source: Processed primary data, 2021

It can be seen from Table 9 that the external least squares method is used to estimate the results of the outer loading test of the auditor's independent variable indicator. The table shows that I1 to I3, which are reflection indicators, have a loading coefficient greater than 0.70 , which means that all construction indicators are valid. The conclusion is that all indicators effectively measure the composition of the auditor's independent variables.

Table 10. Outer Loading Validity Test for Risk-Based Audit Variables

\begin{tabular}{ccc}
\hline & Risk Based Audit & Info \\
\hline ABR1 & 0.949 & Valid \\
ABR2 & 0.899 & Valid \\
ABR3 & 0.944 & Valid \\
ABR4 & 0.894 & Valid \\
ABR5 & 0.907 & Valid \\
\hline
\end{tabular}

Source: Processed primary data, 2021

Based on Table 10, this table shows the estimated results of the outer loading test calculation using PLS based on indicators of risk-based audit variables. From the table and figure, it can be seen that the loading factor ABR1 to ABR5 as a reflection indicator is > 0.70 , which means that all construction indicators are valid. The conclusion is that all indicators effectively measure the construction of risk-based audit variables.

Table 11. Validity Test of Outer Loading Quality Audit

\begin{tabular}{ccc}
\hline & Audit Quality & Info \\
\hline KA1 & 0.892 & Valid \\
KA2 & 0.923 & Valid \\
KA3 & 0.977 & Valid \\
KA4 & 0.913 & Valid \\
\hline
\end{tabular}

Source: Processed primary data, 2021

Based on Table 11, the table shows the estimated results of the outer loading test calculation using PLS as an indicator of the "audit quality" variable. The table shows that KA1 to KA4 are reflective indicators with a loading factor greater than 0.70 , which means that all structural hands are valid. The conclusion is that all indicators effectively measure the structure of the "audit quality" variable.

A reliability test is used as a questionnaire measuring instrument that indicates a variable or structure. If the measuring device is reliable or reliable, it is said that the measuring instrument or instrument in the form of a questionnaire can provide stable or constant measurement results. Therefore, it is necessary to do a reliability test. 
Table 12. Cronbach's Alpha, Composite Reliability and AVE

\begin{tabular}{lcccc}
\hline & $\begin{array}{c}\text { Cronbach's } \\
\text { Alpha }\end{array}$ & $\begin{array}{c}\text { Composite } \\
\text { Reliability }\end{array}$ & $\begin{array}{c}\text { Average Variance Extracted } \\
\text { (AVE) }\end{array}$ & Info \\
\hline Competence & 0.936 & 0.954 & 0.838 & Reliable \\
Independence & 0.928 & 0.953 & 0.872 & Reliable \\
Risk Based Audit & 0.954 & 0.965 & 0.845 & Reliable \\
Audit Quality & 0.945 & 0.961 & 0.859 & Reliable \\
\hline Source: Processed primary data, 2021 & & &
\end{tabular}

The test results based on Table 12 show that the composite reliability and Cronbach alpha results show a satisfactory value, namely the value of each variable is higher than the minimum value of 0.70 . The AVE value generated by all the above constructs is $>0.50$. This shows the high consistency and stability of the instruments used. In other words, all structures, namely the variables of auditor capability, auditor independence, risk-based audit and audit quality, have become appropriate measuring tools, and all problems used to measure each structure have good reliability.

Discriminant validity is related to the following principle: variables exhibited by different structures should not be highly correlated. The method to test the validity of the reflection indicator is to compare the correlation value between the square root of each AVE and its structure. If the value of the square root of AVE is greater than the correlation value between constructs, then it is declared to meet Discriminant validity.

Table 13. Discriminant Validity

\begin{tabular}{llccccc}
\hline & $\begin{array}{l}\text { Risk Based } \\
\text { Audit }\end{array}$ & $\begin{array}{c}\text { Independe } \\
\text { nce }\end{array}$ & $\begin{array}{c}\text { Compete } \\
\text { nce }\end{array}$ & $\begin{array}{c}\text { Audit } \\
\text { Quality }\end{array}$ & $\begin{array}{c}\text { Moderating } \\
\text { Effect I * ABR }\end{array}$ & $\begin{array}{c}\text { Moderating Effect } \\
\text { K * ABR }\end{array}$ \\
\hline Risk Based Audit & 0.919 & & & & & \\
Independence & 0.045 & 0.934 & & & & \\
Competence & 0.798 & 0.033 & 0.916 & & \\
Audit Quality & 0.750 & 0.225 & 0.629 & 0.927 & & \\
Moderating Effect & -0.232 & -0.030 & -0.221 & 0.227 & 1.000 \\
I*ABR & -0.290 & 0.072 & 0.462 & 0.176 & 1.000 \\
Moderating Effect & 0.371 & -0.27 & & \\
K * ABR & & & & &
\end{tabular}

Source: Processed primary data, 2021

Based on Table 13 above, it can be seen that the diagonal is the square root value of the AVE, and the values below are the correlations between components. Thus, it can be seen that the value of the square root of AVE is higher than the correlation value, so it can be concluded that the model is effective because it meets discriminant validity.

The inner model (inner relation, structural model, and substantive theory) describes the relationship between latent variables based on entity theory. The structural factor uses $\mathrm{R}$-squared to evaluate the potential dependent variable. When using PLS to evaluate a model, PLS will first look at the R-squared of each dependent variable. The explanation is the same as the one in the regression. Changes in the R-squared value can be used to evaluate the impact of a particular latent variable on the latent variable, regardless of whether the variable has a substantial effect. 
Table 14. R-Square Construct Variable

\begin{tabular}{lcc}
\hline & R Square & R Square Adjusted \\
\hline Audit Quality & 0.823 & 0.793 \\
\hline Source: Processed primary data, 2021 & &
\end{tabular}

As shown in Table 14 above, the R-Square value of the audit quality variable is 0.823 , which means it is included in the high (high) category. The R-squared value of audit quality is 0.823 or $82.3 \%$, indicating that the audit quality variable can be explained by the auditor's ability and independence variables. Audit-based risk as a moderator variable is $82.3 \%$, and this study can explain the remaining $17.7 \%$-interpretation of other variables that did not exist.

Testing the proposed hypothesis is done by testing the structural model (inner model) by looking at the path coefficients which show the parameter coefficients and the t statistical significance value. In testing the hypothesis, we conducted two kinds of tests, namely direct testing and moderating effect testing.

Table 15. Hypothesis Testing based on Path Coefficient

\begin{tabular}{lccrrc}
\hline & $\begin{array}{c}\text { Original } \\
\text { Sample }\end{array}$ & \multicolumn{1}{c}{$\begin{array}{c}\text { Sample } \\
\text { Mean }\end{array}$} & $\begin{array}{c}\text { Standard } \\
\text { Deviation }\end{array}$ & $\begin{array}{c}\text { T } \\
\text { Statistics }\end{array}$ & \multicolumn{1}{c}{$\begin{array}{c}\text { P } \\
\text { Values }\end{array}$} \\
\hline Kompetensi $\rightarrow$ Kualitas Audit & 0.293 & 0.299 & 0.127 & 2.314 & 0.021 \\
Independensi $\rightarrow$ Kualitas Audit & 0.285 & 0.251 & 0.135 & 2.119 & 0.035 \\
Audit Berbasis Risiko $\rightarrow$ & 0.484 & 0.448 & 0.154 & 3.154 & 0.002 \\
Kualitas Audit & & & &
\end{tabular}

Source: Processed primary data, 2021

Based on the internal weight value consisting of the application of auditor competence (X1) and auditor independence (X3), it is possible to understand the impact on audit quality (Y) partially.

The first hypothesis states that the auditor's ability has a positive and significant effect on audit quality. Table 15 shows that the significance level of the auditor's ability variable is 0.021 , which is smaller than 0.05 . The parameter coefficient value is +0.293 , which is positive. This means that if the value of the $\mathrm{X} 1$ variable increases by one unit and the other independent variables have a fixed value, the value of the Y variable will increase by 0.293. A positive coefficient indicates a direct relationship between the auditor's ability variable (X1) and the audit quality variable (Y). The higher the auditor's ability, the higher the audit quality. This means that $\mathrm{H} 1$ is accepted, so it can be said that the auditor's power has a positive and significant effect on audit quality.

The second hypothesis shows that auditor independence positively and significantly affects audit quality. Table 15 shows that the significance level of the auditor's independent variable is 0.035 , more diminutive than 0.05 . The parameter coefficient value is +0.285 , which is positive. This means that if the value of the X2 variable increases by one unit and the other independent variables have a fixed value, the value of the $\mathrm{Y}$ variable will increase by 0.285 . The positive coefficient indicates a significant relationship between the auditor's independent variable (X2) and the audit quality variable (Y). The higher the independence 
of the auditor, the higher the audit quality. This means that $\mathrm{H} 2$ is accepted, so it can be said that auditor independence has a positive and significant effect on audit quality.

Table 16. Hypothesis Testing based on Moderating Effect

\begin{tabular}{|c|c|c|c|c|c|}
\hline & $\begin{array}{l}\text { Original } \\
\text { Sample }\end{array}$ & $\begin{array}{c}\text { Sample } \\
\text { Mean }\end{array}$ & $\begin{array}{c}\text { Standard } \\
\text { Deviation }\end{array}$ & T Statistics & P Values \\
\hline $\begin{array}{l}\text { Moderating Effect } \mathrm{K}^{*} \mathrm{ABR} \rightarrow \\
\text { Audit Quality }\end{array}$ & 0.354 & 0.370 & 0.111 & 3.183 & 0.002 \\
\hline $\begin{array}{l}\text { Moderating Effect I * ABR } \rightarrow \\
\text { Audit Quality }\end{array}$ & 0.352 & 0.306 & 0.174 & 2.027 & 0.043 \\
\hline
\end{tabular}

Based on the value of the inner weight, which consists of Implementation of Auditor Competence (X1) and Auditor Independence (X2), it can be seen partially its effect on Audit Quality (Y) moderated by Risk-Based Audit (M). The third hypothesis shows that there is a significant positive difference between the auditor's audit quality capability and moderation in risk-based auditing. Table 16 shows that the significance level of the auditor's ability variable is 0.002 , more diminutive than 0.05 . The parameter coefficient value is +0.354 , which is positive. This means that if the value of the $\mathrm{X} 1$ variable (moderated by the $\mathrm{M}$ variable) increases by one unit and the other independent variables have a fixed value, the value of the $\mathrm{Y}$ variable will increase by 0.354 . The positive coefficient indicates that there is a one-way relationship between the auditor's ability variable (X1) and the audit quality variable $(\mathrm{Y})$ adjusted for the risk-based audit variable $(\mathrm{M})$. The more competent the auditor is to lead a risk-based audit, the better the audit quality. This means that $\mathrm{H} 3$ is accepted, so it can be said that an audit through a risk-based audit will have a positive and significant impact on audit quality. The value of the intermediate parameter coefficient between competence and risk-based audit quality is greater than the auditor's audit quality parameter coefficient $+0.293+0.354$. This shows that the risk-based audit variable is a moderating variable that can strengthen the relationship between auditor ability and audit quality.

The fourth hypothesis indicates a clear positive difference between auditor independence on audit quality and conformity in risk-based auditing. Table 16 shows that the significance level of the auditor's independent variable is 0.043 , more diminutive than 0.05 . The parameter coefficient value is +0.352 , which is positive. This means that if the value of the $\mathrm{X} 2$ variable (moderated by the $\mathrm{M}$ variable) increases by one unit and the other independent variables have a fixed value, the value of the $\mathrm{Y}$ variable will increase by 0.352 . The positive coefficient represents a one-way relationship between the auditor's independent variable (X2), which is audited by the risk-based audit variable (M), and the audit quality variable (Y). The higher the auditor's independence on risk-based audits, the higher the audit quality. This means that $\mathrm{H} 4$ is accepted, so it can be said that auditor independence has a positive and significant effect on the quality of audits carried out by risk-based audits. The coefficient value of the conformity parameter between auditor independence and risk-based audit quality assessment is greater than that of the auditor independence parameter of audit quality $+0.285+0.352$. This shows that the risk-based audit variable is a moderating variable that can strengthen the relationship between auditor independence and audit quality. 


\section{DISCUSSION}

The results showed that the ability variable had a positive and significant effect on audit quality. The relationship between competence and audit quality is positive, which indicates that the stronger the auditor's competence, the better the audit quality. The auditor will use his knowledge and experience in carrying out his duties so that the auditor's professional knowledge will continuously develop and support the auditor's audit capability. The most crucial indicator informing the ability variable is the auditors' knowledge. With this knowledge, they will better understand and have a deeper understanding of various issues. It will be easier to keep up with increasingly complex developments worldwide. Auditing environment To improve their abilities, auditors must have personal qualities obtained through formal training and education. This research follows the attribution theory developed by (Wiratmaja, 2017) which argues that a person's behavior is determined by internal forces (i.e., factors from within the person, such as ability or effort) and external forces (i.e., external factors, such as work or work). (Mansouri et al., 2009) competent or energetic auditors will use their ability to conduct audits to provide high-quality results. The results of hypothesis testing indicate that the independent variable has a positive and significant effect on audit quality. This means that audit quality can be achieved if the auditor has good independence. Auditors must have a fair attitude, have no personal interest, and are not easily influenced by related parties when providing opinions or conclusions to conduct a high-quality audit. The most important indicator that forms the auditor's independent variable is the indicator of the independence of the implementation of the work. Auditors will not be influenced by fraudulent parties when conducting audits. This study follows the attribution theory developed by (Wiratmaja, 2014) which argues that a person's behavior is determined by internal forces (i.e., factors from within the person, such as ability or effort) and external forces (i.e., external factors, such as work or work). (Octavia and Widodo, 2015) also suggests that auditors with good independence will not be affected by the pressure exerted by leaders and customers when conducting audits, so that audit results have higher quality.

The results of hypothesis testing indicate that the auditor's ability affects quality audits governed by risk-based audits. The relationship between the risk-based audit chairman's ability and audit quality is positive, which indicates that the more competent the auditor is, the more knowledge he has about accounting, auditing, and fraud, and the more skilled he is in performing audit work. Responsibility. Because the auditor first assesses inherent risk and control risk at the start of a planned inspection. If intrinsic and control chances are high, the auditor will determine control risk and negligible acceptable audit risk. Thus improving audit quality. This research is in line with a study conducted by research (Prasanti et al., 2019) which shows that the application of competence, if moderated by risk-based auditing, will have a positive and significant impact on audit quality. The results of hypothesis testing indicate that auditor independence will be affected by risk-based auditing, which will affect audit quality. The relationship between autonomy governed by risk-based auditing and audit quality is positive. This may be due to higher auditor independence. Therefore, during the audit, the auditor finds that the items in the financial statements are most likely to be audited the wrong information. Therefore, the amount of audit evidence collected by the auditor is usually more than items that are likely not to be missed in the financial statements, which can improve audit quality. This research is supported by research conducted by (Daniels and 
Booker, 2011), which shows that the application of independence if moderated by riskbased auditing, will have a positive and significant effect on audit quality.

\section{CONCLUSION}

Based on the results of our study, we conclude that: 1 . Auditor ability has a positive and significant effect on audit quality. The stronger the auditor's knowledge, the better the audit quality. 2. Auditor independence has a positive and significant effect on audit quality. The better the independence of the auditor, the better the audit quality. 3. Auditors' ability positively and significantly affects audit quality controlled by risk-based auditing. The more qualified auditors strengthened through risk-based audits, the better the audit quality. 4 . Auditor independence has a positive and significant effect on the quality of audits carried out by risk-based audits. The better the auditor's independence through a risk-based audit, the better the audit quality will be.

\section{REFERENCES}

Adianita, A. S., Mujanah, S., dan Candraningrat. (2017). Kompetensi Karyawan , Emotional Quotient Dan Self Efficacy Pengaruhnya Terhadap Organizational Citizenship Behavior Dan Kinerja Karyawan Pada. 17(1).

Ahmad, M. (2015). The Impact Of Ex-Auditors' Employment With Audit Clients On Perceptions Of Auditor Independence. Procedia - Social And Behavioral Sciences, 172, 479-486. Https://Doi.Org/10.1016/J.Sbspro.2015.01.387.

Anis, A. (2014). Auditors' Perceptions Of Audit Firm Rotation Impact On Audit Quality In Egypt. Accounting \& Taxation, 6(1), 105-120.

Ardhani, L., Subroto, B., and Hariadi, B. (2019). Does Auditor Independence Mediate The Relationship Between Auditor Rotation And Audit Quality? Jabe (Journal Of $\begin{array}{lllll}\text { Accounting And } & \text { Business }\end{array}$ Https://Doi.Org/10.26675/Jabe.V4i1.8145.

Arianti, K. P., Sujana, E., dan Putra, I. M. P. A. (2014). Pengaruh Integritas, Objektivitas Dan Akuntabilitas Terhadap Kualitas Audit(Studi Pada Inspektorat Kabupaten Buleleng). E-Journal S1 Ak Universitas Pendidikan Ganesha, Vol: 2 No: 1, 1(1).

Daniels, B. W., and Booker, Q. (2011). The Effects Of Audit Firm Rotation On Perceived Auditor Independence And Audit Quality. Research In Accounting Regulation, 23(1), 78-82. Https://Doi.Org/10.1016/J.Racreg.2011.03.008.

Duréndez Gómez-Guillamón, A. L., and Maté Sanchez-Val, M. (2012). The Geographical Factor In The Determination Of Audit Quality. Revista De Contabilidad-Spanish Accounting Review, 15(2), 287-310. Https://Doi.Org/10.1016/S11384891(12)70046-8.

Elizabeth, V., dan Laksito, H. (2017). Pengaruh Time Budget Pressure Terhadap Kualitas Audit Dan Budaya Etis Sebagai Variabel Mediator. Jabe (Journal Of Accounting And Business Education), 6, 1-10.

Hai, P. T., Toan, L. D., and Quy, N. L. D. (2019). Effect Of Audit Rotation, Audit Fee And Auditor Competence To Motivation Auditor And Audit Quality: Empirical Evidence In Vietnam. Academy Of Accounting And Financial Studies Journal, 23(2), 1-14. 
Ihsanti, E. (2014). Pengaruh Kompetensi Sumber Daya Manusia Dan Penerapan Sistem Akuntansi Keuangan Daerah Terhadap Kualitas Laporan Keuangan Daerah (Studi Empiris Pada Skpd Kab. Lima Puluh Kota). Fakultas Ekonomi Universitas Negeri Padang.

Ilham, M., Suarthana, W. R., dan Surono, S. E. (2019). Pengaruh Kompetensi , Integritas , Dan Motivasi Terhadap Kualitas Audit ( Studi Empiris Pada Inspektorat Kota Bogor ). Fakultas Ekonomi, Universitas Pakuan.

Lesmana, R., dan Machdar, N. M. (2015). Pengaruh Profesionalisme, Kompetensi, Dan Independensi Auditor Terhadap Kualitas Audit. Kalbis Socio: Jurnal Bisnis Dan Komunikasi, 2(1), 33-40.

Luh, N., Betrisia, T., Luh, N., Erni, G., dan Sujana, E. (2015). Pengaruh Kompetensi , Professional Judgment Auditor, Tingkat Pendidikan Terhadap Tingkat Independensi ( Studi Empiris Pada Kantor Akuntan Publik Se-Bali ). E-Journal S1 Ak Universitas Pendidikan Ganesha, 3(1).

Mansouri, A., Pirayesh, R., and Salehi, M. (2009). Audit Competence And Audit Quality: Case In Emerging Economy. International Journal Of Business And Management, 4(2), 17-25. Https://Doi.Org/10.5539/Ijbm.V4n2p17.

Meidawati, N., and Assidiqi, A. (2019). The Influences Of Audit Fees, Competence, Independence, Auditor Ethics, And Time Budget Pressure On Audit Quality. Jurnal Akuntansi \& Auditing Indonesia, 23(2), 117-128. Https://Doi.Org/10.20885/Jaai.Vol23.Iss2.Art6.

Muslim, M., Rahim, S., Faisal, M., Pelu, A. R., dan Pratiwi, A. (2020). Kualitas Audit : Ditinjau Dari Fee Audit, Risiko Audit Dan Skeptisme Profesional Auditor Sebagai Variabel Moderating. 8(1), 9-19.

Ningtyas, W. A., Studi, P., Fakultas, A., dan Aris, M. A. (2016). Independensi , Kompetensi , Pengalaman Kerja , Dan Due Professional Care : Pengaruhnya Terhadap Kualitas Audit Yang Dimoderasi Dengan Etika Profesi ( Studi Empiris Pada Kantor Akuntan Publik Se-Jawa Tengah Dan DIY ) Pendahuluan.

Octavia, E., and Widodo, N. R. (2015). The Effect Of Competence And Independence Of Auditors On The Auditquality. Research Journal Of Finance And Accounting Www.Iiste.Org Issn, 6(3), 1-6. Www.Iiste.Org

Pinto, M., Rosidi, R., and Baridwan, Z. (2020). Effect Of Competence, Independence, Time Pressure And Professionalism On Audit Quality (Inspeção Geral Do Estado In Timor Leste). International Journal Of Multicultural And Multireligious Understanding, 7(8), 658. Https://Doi.Org/10.18415/Ijmmu.V7i8.2013.

Prasanti, D. H., Ramadhanti, W., and Puspasari, N. (2019). Effect Of Independence, Work Experience And Competence On Audit Quality With Professional Ethics As Moderating Variable. Jurnal Akuntansi Aktual, 5(3), 223-233. Https://Doi.Org/10.17977/Um004v5i32019p223.

Purnamasari, P. P. D., dan Merkusiwati, N. K. L. A. (2017). Pengaruh Kompleksitas Tugas, Independensi, Dan Kompetensi Terhadap Kualitas Audit Dengan Integritas Auditor Sebagai Variabel Pemoderasi. E-Jurnal Akuntansi Universitas Udayana, 19, 24962526.

Raharjo, E. (2005). (Agency Theory Vs Stewardship Theory In The Accounting Perspective). 
Santosa, P. W., Tambunan, M. E., and Kumullah, E. R. (2020). The Role Of Moderating Audit Quality Relationship Between Corporate Characteristics And Financial Distress In The Indonesian Mining Sector. Investment Management And Financial Innovations, 17(2), 88-100. Https://Doi.Org/10.21511/Imfi.17(2).2020.08.

Sarwoko, I., and Agoes, S. (2014). An Empirical Analysis Of Auditor's Industry Specialization, Auditor's Independence And Audit Procedures On Audit Quality: Evidence From Indonesia. Procedia - Social And Behavioral Sciences, 164(August), 271-281. Https://Doi.Org/10.1016/J.Sbspro.2014.11.077.

Setyowati, D. H. (2019). Pengaruh Efisiensi Operasional Terhadap Return On Assets Pada Bank Umum Syariah Di Indonesia. Jurnal Masharif Al-Syariah, 4(2), 39-53.

Sulaiman, N. A., Shahimi, S., and Nashtar Singh, R. K. (2019). People And Audit Process Attributes Of Audit Quality: Evidence From Malaysia. Management And Accounting Review (Mar), 18(2), 47. Https://Doi.Org/10.24191/Mar.V18i2.715.

Trianto, A. (2017). Analisis Laporan Keuangan Sebagai Alat Untuk Menilai Kinerja Keuangan Perusahaan Pada Pt. Bukit Asam (Persero) Tbk Tanjung Enim. 8(03).

Van Asseldonk, M. A. P. M., and Velthuis, A. G. J. (2014). Risk-Based Audit Selection Of Dairy Farms. Journal Of Dairy Science, 97(2), 592-597. Https://Doi.Org/10.3168/Jds.2013-6604.

Wiratmaja, I. D. N. (2014). Pengaruh Ukuran Perusahaan , Komite Audit , Penerapan International Financial Reporting Fakultas Ekonomi Dan Bisnis Universitas Udayana ( Unud ), Bali , Indonesia Menginvestasikan Modal Mereka Pada Perusahaan Go Public ( Indah , 2008 ) . Untuk Dapat Lama . 1, 63-78.

Wiratmaja, I. D. N. (2017). Pertimbangan Materialitas Sebagai Variabel Pemoderasi Pengaruh Etika Profesi Dan Kompetensi Terhadap Ketepatan Pemberian Opini Auditor. E-Jurnal Akuntansi, 20(2), 1280-1309. Https://Doi.Org/10.24843/Eja.2017.V20.I02.P15.

Zhang, Y., Zhou, J., and Zhou, N. (2011). Audit Committee Quality, Auditor Independence, And Internal Control Weaknesses. Ssrn Electronic Journal, 607. Https://Doi.Org/10.2139/Ssrn.925732. 